\title{
Bajapuik Tradition the Traditional Marriage in Minangkabau
}

\author{
Hafizatul Anisa ${ }^{1}, \operatorname{Aman}^{2}$, Dyah Kumalasari ${ }^{3}$ \\ ${ }^{1,2,3}$ History Education Study Program, Faculty of Social Sciences, Universitas Negeri Yogyakarta, Indonesia \\ hafizatulanisa.2019@student.uny.ac.id
}

\begin{abstract}
Bajapuikis a tradition of the Minangkabau people native to the Padang Pariaman area which is carried out in a traditional marriage process. Bajapuik is the custom of the Minang community in respecting the position of men from Padang Pariaman but not detrimental to women as the biological bundo in the rumah gadang. Bajapuik has become a mandatory tradition at wedding ceremonies in Padang Pariaman by picking up / buying the groom using money whose nominal value is determined by means of family congregation and traditional leaders. Writing this article aims to describe the cultural customs of marriage in Minangkabau with a focus on the study of the Bajapuik tradition in Padang Pariaman. The method used in writing this scientific article is a qualitative method with a descriptive approach.
\end{abstract}

Keywords

Bajapuik tradition;

Minangkabau custom;

marriage

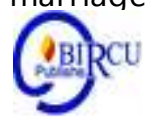

\section{Introduction}

Indonesia is a country with a variety of ethnicities and cultures. Consisting of thousands of islands separated by the ocean, making this country has a diverse ethnicity and culture. Ethnic and cultural diversity inhabiting Indonesia from Sabang to Merauke, including the Minangkabau ethnicity or Minangkabau culture.

Minangkabau itself is a term for people who come from West Sumatra, even the people of West Sumatra are often referred to as the Minang people. The term Minang people to the people of West Sumatra is given by outsiders where the Minang people have a Marantau habit or come out of their home area.

The people of West Sumatra are very synonymous with Minangkabau traditional culture, so it is not surprising that the Minang people still maintain their culture today, seen in the habits of the Minang people with the Marantau culture and the spread of the Minang people in Indonesia. With the trading skills they have, the Minang people are able to survive wherever they stand, with this the Minangkabau people have a philosophy of life, that is, where the earth is stepped on, it is directly viewed (Hakimy, 2001: 1) which means that wherever Minang people are, then there they must be able to survive and conform to local regulations.

The Minangkabau tradition adheres to a matrilineal system. The matrilineal system is the lineage of the Minangkabau people calculated according to the mother's line so that the tribe of the child is according to the tribe of the mother. Women are protected by a matrilineal inheritance system, where houses and land are reserved for women. Although on the other hand, control rights remain in the hands of men, namely mamak (uncle).

According to Putiah (2003: 291) matrilineal in Minangkabau in its early days was born from imitating natural life. In the example that plants grow near their parents, then animals / animals are raised and fed and grouped in one parent group. Human nature is even wiser, that is, apart from giving birth to a child, the mother also breastfeeds, feeds and cares for the child so that it is close to the mother. Furthermore, after the arrival of Islam, the philosophy of life 
of the Minangkabau people was further refined with the custom of basandi syara ', syara' basandi Kitabullah, meaning that custom is based / supported by the Islamic religious law which is based on the Al-Quran and Hadith.

The Minangkabau custom is one of the unique customs in Indonesia, especially since the people adhere to the matrilineal system. Minangkabau has customs that regulate the order of society both individually, in groups and socially. The order that has been regulated has become the basis for the life of the Minangkabau people.

\section{Review of Literatures}

Tradition is a culture as a whole that can change. However, there are customs that do not change, such as the word mamangan: cloth is worn out, it is good to be worn new, meaning that when it is worn it will continue to wear out, while the customs that are used continuously will always last (AA Navis, 1982: 88). Therefore, in Minangkabau, there are customs that remain unchanged and there are customs that change, so these customs are divided into four categories: Culture that is actually customary, customary, customary customary, and customary tradition.

Pane (2020) states that tradition is something that is passed down from the heritage of the ancestors to the next generation in a relay descends performed by the indigenous communities that have become deeply entrenched the culture in life. Customs and traditions include the creation and work of human beings who have become convictions in regulating the social order of life.

In traditional ceremonies there is an embodiment of religious values, the rules that link human relationships among humans. Then the community has norms or rules which then become the customs of the community and function to regulate all behavior in their lives. Between one community and another community have different norms or customs (Soekanto, 2004: 182). Each nagari in Minangkabau has different customs and habits, but the Minangkabau people still maintain the integrity of the customs themselves.

Marriage is the process by which two people make their relationship public, official, and permanent. It is the joining of two people in a bond that putatively lasts until death. Over the course of a relationship that can last as many as seven or eight decades, a lot happens. Personalities change, bodies age, and romantic love waxes and wanes. And no marriage is free of conflict. (Jamaluddin, 2018)

In the marriage system in Minangkabau, there are rules that are drawn up by deliberation and consensus among the chiefs and niniak mamak in each nagari in West Sumatra. This rule is known as adat nan taradat or adat teradat (Hakimy, 1997: 110). Adat nan taradat or traditional customs are customary regulations that are decided by consensus or community deliberation which applies in a particular village.

The Minangkabau community adheres to a marriage pattern system that is exogamous, meaning that marriages must leave their parent tribe. In this exogamous marriage system, people of the same ethnicity are not allowed to marry each other even though they have developed into hundreds of people, because the Minangkabau people who are of the same ethnic group are considered badunsanak or brothers. The exogamous marriage system continues in Minangkabau and is maintained intact based on consensus in a village. In addition to deliberation, the Minangkabau people have procedures for marriage, namely the syarak (religious) procedure that is meant when the bride and groom pronounce the marriage 
contract in front of Kadhi. While the customary procedures are rules that apply to a Nagari in Minangkabau and must be obeyed by consensus.

Apart from the exogamous marriage system, in Minangkabau there is also a tradition of marriage with the Bajapuik tradition (pick-up) or lost money in Padang Pariaman.

The Bajapuik (pick-up) tradition is a marriage tradition that is characteristic of the Padang Pariaman area. Bajapuik is seen as an obligation for the woman's family to give a certain amount of money or objects and then it is agreed upon to the male party (the prospective husband) before the marriage contract is carried out (Elly, 1997: 52). Lost money is a gift from the woman's family to the male which is given by the woman at the ceremony to sweep the marapulai and will be returned to (the woman's bride) when she visits her parents-in-law for the first time (manjalang event).

Marriage customs in Padang Pariaman consist of various series. There are activities before marriage, activities during marriage and after marriage. The activities before marriage in Padang Pariaman consist of maratak tando, shortening hetongan, batimbang tando (maminang) and fixing pick-up money or what is called the Bajapuik tradition (Ramot Silalahi, 200: 28). The stipulation of the japuik money is usually stipulated in the ceremony before the wedding, usually the groom's (mother's uncle) will confer with the family of the prospective anak daro (the prospective bride).

\section{Discussion}

\subsection{Marriage Customs in Minangkabau}

Marriage is sunatullah, the natural law of the world. Mating is carried out by humans, animals and even by plants which consist of two partners. In Law No.1 of 1974 Chapter 1 Article 1 , it is stated that marriage is a physical and spiritual bond between a man and a woman as husband and wife with the aim of forming a happy and eternal family (household) based on Almighty God.

In Minangkabau culture, marriage is regulated according to the matrilineal system, every child born from a marriage in Minangkabau will enter the parent tribe, then where the marriage is a family affair according to the following customary mamangan; kawin jo niniak mamak, nikah jo parampu, which means that from looking for a partner, making an agreement, getting an engagement, until the marriage is carried out must be a family matter. After marriage, the husband comes or lives at his wife's house (matrilocal) because the woman in Minangkabau is bundo kanduang, who has power over the property of the pusako and the rumah gadang (Navis, 1984: 193).

The marriage system in Minangkabau is exogamous, that is, marriages have to leave their parent tribe (Navis, 1984: 197), meaning that people of the same tribe are not allowed to marry each other even though they have developed into hundreds of people, because the Minangkabau people who are of the same ethnic group are considered badunsanak or siblings.

Marriage in the Minangkabau tradition is very important and its implementation is well regulated. Marriage for the Minangkabau people is not only the union of two people who love each other, but the formation of two large families who vow to be together forever (Yakub, 1995: 45). Therefore, Minangkabau marriage has an ideal concept of marriage; (1) ideal marriage, (2) prohibited marriage.

An ideal marriage is a marriage between a family that is still related according to custom, that is, a marriage between a child and a nephew called homecoming ka mamak or 
returning $\mathrm{ka}$ bako, which means marrying a mamak child (the son of a father's brother), while a home marriage is ka bako (marrying the father's nephew).

Prohibited marriage is a form of marriage that is strictly prohibited for the Minangkabau community because it can damage the customary system, the form of marriage is a sasuku or sakaum marriage, even though there is no kinship relationship. Minangkabau people think that sasuku is bandunsanak (brothers).

The marriage procession in the Minangkabau tradition is divided into two, namely syarak and custom. As for what is meant by Islam, namely the procession of the marriage contract that determines the validity of a marriage. Traditionally, there is one stage which, if not implemented, is deemed not to be legally married, namely the wedding party or marriage ceremony. Baralek is an announcement to society that a pair of young people will be united in a marriage bond, and the Minagkabau call the wedding party Baralek (Navis, 1984: 198). Therefore, after the contract takes place, there should be a baralek (party) event or baralek (party) as has become a customary decree.

The implementation of marriage in the Minangkabau community has a series of different events and the custom of salingka nagari applies which means that each Nagari in Minangkabau has a diverse range of customs but does not escape from the customary rules itself. In the Minangkabau custom, it is the woman who comes to propose because the man (candidate for marriage) will be brought to the environment of female relatives. Even so, that does not mean that the male party should not come to propose. The marriage system is carried out by men and some by women, so such differences are called adat salingka nagari.

This difference is not something that is contradictory and it is proven that until now it is still being carried out by the people in Padang Pariaman, known as the Bajapuik tradition or other terms, manjapuik anak bujang (picking up boys) with money called lost money, japuik money ( pickup). Bajapuik (japuik; pick-up) is a marriage tradition that is characteristic of the Padang Pariaman area.

\subsection{Bajapuik Tradition History a. Padang Pariaman}

The people of Padang-Pariaman, still according to the tambo narrative, descended from the Minangkabau darek, from the interior of central Sumatra. The population of this area according to the annual local government report, based on recognition from the people of Kab. Padang-Pariaman itself, originates from Pagaruyung Batusangkar, which is located in Darek Minangkabau.

Rantau Pariaman, according to Dobbin, was founded by immigrants who came from Batipuh who were considered to have royal foundations. In a time that is not known for certain, it is possible that since $1300 \mathrm{AD}$, these early nomads (successors) descended in waves to the west coast and opened settlements.

Padang Pariaman is one of the districts in West Sumatra which has been established since 1956 with its capital, Pariaman. As time went on in 2002, Pariaman was designated as an autonomous city in West Sumatra, so the district capital area had to be moved outside the Pariaman autonomous city area. The relocation of the regency capital only occurred in 2008 because Pariaman became an autonomous city in West Sumatra Province led by a mayor. Based on Government Regulation (PP) Number 79, the capital of Padang Pariaman Regency was moved to Parik Malintang District, Six Lingkung District, and Padang Pariaman Regency. 


\section{b. Bajapuilk Tradition}

The Bajapuik tradition in Padang Pariaman has indeed occurred from time immemorial, even this statement was strengthened when Islam entered and began to develop in Minangkabau. Bajapuik tradition of marriage in Padang Pariaman originates from the story of the marriage of the Prophet Muhammad, a story that begins with Siti Khadijah who put her heart into the Prophet Muhammad with her title Al-amin (a trusted person). From this story, it is said that the Prophet Muhammad SAW when he married Khadija was paid (picked up) by Khadija with a hundred sheep. Khadija, as a wealthy woman, intends to respect the Prophet Muhammad SAW by giving some of her assets with the intention of being able to lift the drajat of Prophet Muhammad who had nothing at that time.

The majority of people in Minangkabau adhere to Islam, in line with the philosophy of the Minang people; adat basandi syara ', syara' basandi Kitabullah, which means custom based / sustained by the Islamic religious law which is based on the Koran and Hadith. Then the Bajapuik tradition was further refined in accordance with the customary provisions in the Minangkabau nagari.

The Bajapuik tradition is increasingly being preserved by the Minangkabau people, especially in the Padang Pariaman area as a trade mark with a term that is always attached to a distinctive wedding procession. Basically the Bajapuik tradition is not a form of human trafficking or demeaning one's position, but rather a cultural tradition by honoring one's partner in the manner prevailing in Nagari Padang Pariaman.

The Bajapuik tradition is a series of marriage customs that are carried out before the marriage contract, traditionally the woman who comes to propose is the woman because the man will be brought to the environment of a female relative. Regarding how to propose to a man in Padang Pariaman, it is a woman who proposes to a man's place, then it is agreed how much money / pick-up money. The term pick-up money means returning, for example being picked up 10 ameh, this is the size of the person who used to use ameh, it will be received by the male as much as 10 ameh, and then this pickup money will return again to the woman in the procession of pambarian bako / gifts from the male side. -Male of the prospective bride and groom. So from this pick-up money is given the term back, because in the Bajapuik tradition there is no harm to the woman as the giver of the pick-up money (Navis, 1984: 199).

Uniquely, the amount of pick-up money given to the bride and groom in Padang Pariaman is based on the gala (title) or lineage obtained from the father. Gala in Padang Pariaman, starting from Sidi, Sutan, Bagindo. The gala which has the highest level / the best position, the Sidi gala which is taken from the word "Syaidina" then refined into Sidi, then the Sutan gala which comes from the word "Sultan", and then the Bagindo gala which comes from the word "King King" . For the amount of pickup money, it is calculated by gala or lineage owned by the prospective bride, if the prospective bride is Minangkabau but does not have a gala, then the amount / amount of the pickup fee is only voluntary or as capable as the family of the prospective bride. But if the prospective groom has a gala,

The progress of this era and the influx of modernization in Minangkabau, most of the Minangkabau people have studied up to university. This of course also changes the traditional system that exists in the village, especially the Bajapuik (pickup money) tradition in Padang Pariaman has also changed, where the pickup money that was previously valued based on the gala (nasab) owned by the prospective groom is now already changed. The amount of pick-up money that will be given by the woman to the prospective groom is determined by the level of education, occupation and position obtained. Usually the money for pickup was valued in ameh (gold), now it is replaced with rupiah currency, and some even use a vehicle. After determining the pick-up money, then the traditional wedding procession was continued with the batimbang tando event. Batimbang tando means to determine the sign. 
The ceremony was accompanied by a commando batimbang. The commandos are given in various ways, especially for the people of Padang Pariaman, the procession of batimbang tando is marked by a ring tied with yellow cloth with the philosophy that there has been a meeting of two families by tying a yellow cloth as a sign of seriousness in tying a pair of young people who will be being married, this indicates that there has been a batimbang tando procession (Hakimy, 1997: 110).

\section{c. Bajapuik Tradition Process}

Traditions are customs that are born from generation to generation and develop and are carried out in society. Tradition includes the continuity of the past in the present rather than simply addressing the fact that the present originates from the past. Tradition is conceptualized as a whole material objects and ideas that come from the past but really still exist today, have not been destroyed, destroyed, thrown away, or forgotten (Sztompka, 2004: 69).

Pick-up money is a certain value that is returned to the woman when she visits her parents-in-law (manjalang). Pick-up money is given to the party in the form of rupiah, and returned to the woman, usually in the form of gifts, such as feelings, other women's equipment.

In general, the Bajapuik is a tradition practiced by the Minangkabau people from the Padang Pariaman area in the traditional marriage procession, because in the matrilineal system the position of the husband is urang sumando, who is the person who comes. Therefore, coming to the deck of the dipanggia tibo, the dianta deck, means coming because it was called, arrived because it was delivered, so as an example of urang sumando in Minangkabau. The giving of pick-up money was made with the agreement of both parties (Riza Mutia, 2000: 22). As for in the process of paying pick-up money / japuik money according to the Provincial Dekpendikbud. West Sumatra, as follows:

First, the determination of japuik money is determined at the time of the Bajalan at nan kalam, which means deliberation, consensus between the ninik mamak of the prospective groom and the parents of the prospective groom in determining the amount of collected money. The amount offered to the prospective bride is of course adjusted to the gala and the work procession. For example, Abu is a man who has a bachelor's degree and has become an employee, the amount of money he will offer is Rp. 30,000,000, - up to Rp. 35,000,000, -.

Second, the night of beretongor referred to as batimbang tando. In this process, the promise is tied, usually the binding of the promise is marked with a sign in the form of a ring, and then if this promise is broken by one of the parties, the party who breaks the promise will be fined. Usually the batimbang tando procession is marked by the agreement regarding the day and date of the wedding.

Third, the wedding ceremony and the night of the baretong, until the time of the consent ceremony, then the reception of the party / baralek, then the process of the night of the baretong. In this process, the pick-up money is handed over to the groom's family consisting of ninik mamak and urang mudo (uncle and traditional leaders), and then the groom has officially resided and settled in the bride's house and is referred to as urang sumando or someone who comes.

Fourth, wedding party (baralek). After the specified time arrives, the implementation of the wedding ceremony which is usually held with a wedding party. It is like a wedding party in general that is determined in the community and in accordance with the customs and traditions in Padang Pariaman. Only the traditional bridal clothing and wedding decorations 
are the easiest to indicate that the ongoing wedding is a baralek event for the Minang Pariaman community.

Each area in Minangkabau has its own dank characteristics on traditional clothes at weddings. The surrounding Padang Pariaman area has a distinctive and striking characteristic, namely with traditional clothing with a bright red color, while some areas in Minangkabau also wear traditional clothes with red, but for traditional wedding clothes in Padang Pariaman always use bright red. As for other areas such as Payakumbuh, Batusangkar and Bukittinggi using traditional wedding clothes nuanced in black and gold yellow.

The existence of japuik money (pick-up money) is actually part of the traditions of the Minangkabau community, especially Padang Pariaman, by interpreting the Bajapuik which is the inauguration of the forms of gifts given at wedding ceremonies. A simple form can be seen in all areas in Minangkabau, for example the traditional pasture tando around the Kamang and Magek areas in the highlands of West Sumatra, Bukittinggi. Perhaps because of the influence of the Padang Pariaman community in trading, then the types of gifts adjusted to the socio-economic conditions and could not be separated from the customs in the local area.

\section{Conclusion}

In Minangkabau culture, marriage is regulated according to a matrilineal system, every child born from a marriage in Minangkabau will enter the parent tribe, then where marriage matters are family matters according to the following customary mamangan; kawin jo niniak mamak, nikah jo parampu, which means that from looking for a partner, making an agreement, getting an engagement, until the marriage is carried out must be a family matter. After marriage, the husband comes or lives at his wife's house (matrilocal) because the woman in Minangkabau is bundo kanduang, who has power over the property of the pusako and the rumah gadang (Navis, 1984: 193). The Minangkabau community adheres to a marriage pattern system that is exogamous, meaning that marriages must leave their parent tribe.

Bajapuik This is a tradition carried out by the Minangkabau native of the Padang Pariaman area in the traditional marriage procession, because in the matrilineal system the position of the husband is urang sumando who is the person who comes. Therefore, coming to the deck of the dipanggia tibo, the dianta deck, means coming because it was called, arrived because it was delivered, so as an example of urang sumando in Minangkabau. Where the Bajapuik tradition in the special marriage customs of the Padang Pariaman community does not harm any party, the things / pick-ups given to the men are then returned to the women in the form of family gifts from the groom to the bride. Then the tradition continues to this day, I as a writer also realize that until now my family who comes from Pariaman.

\section{References}

A A Navis. (1984). Alam Terkembang Jadi Guru. Jakarta: PT Grafity Press

Bakhtiar, et al. (2005). Ranah Minang Ditengah Cakrawala Kristenisasi. Jakarta: PT Bumi Aksara

Buyung 60 Tahun Tokoh Adat

Bunga Moeleca, (2015) Kontruksi Realitas Makna Bajapuik Pada Pernikahan bagi Perempuan Pariaman Di Kecamatan Pesir Penyu. Jurnal FISIP UNRI, Vol 2, No 1, 2015

Elly, et al. (1997). Tata Cara Perkawinan Adat Istiadat Minangkabau. Elly Collection 
Deppendikbud Provinsi Sumatera Barat. (1978). Adat Upacara Perkawinan Derah Sumatera Barat.

Ernatip, et al. (2014). Kedudukan Peran Bundo Kanduang. Balai Pelestarian Nilai Budaya Padang.

Hafizah, (2017) Tradisi Uang Japuik dan Uang Hilang dalam Sistem Perkawinan Di Nagari Adat Tandikek Kecamatan Patamuan Kabupaten Padang Pariaman. Jurnal Kepemimpinan dan Pengurusan Sekolah, STKIP Ahlussunnah Bukittinggi, Vol 2, No 1, Th 2017.

Helmawati 59 Tahun Ibu Rumah Tangga

Idrus Hakimy. (1997). Pegangan Penghulu, Bundo Kanduang, Pidato Alam Pasambahan Adat Minangkabau. Bandung: PT Remaja

Jamaluddin. (2018). AL Ghazali's View Regarding to the Witness in Islamic Wedding Ceremony. Budapest International Research and Critics Institute-Journal (BIRCIJournal). P. 01-10.

Jhony 54 Tahun, Wali Korong Kec VII Sungai Sariak Kabupaten Padang Pariaman Period 2014-2019

Pane, A., et al. (2020). The Performance of Mangupa Tradition in Angkola Custom, Medan, Indonesia. Budapest International Research and Critics Institute-Journal (BIRCIJournal). P. 1747-1757

Ririanty, et al. (2012) Uang Japuik Dalam Adat Perkawinan Padang Pariaman di Bandar Lampung. Jurnal Penelitian Kebudayaan UNILA.

Riza Mutia. (2000). Upacara Adat Perkawinan di padang Pariaman. Museum Negri Prov Sumatera Barat.

Savvy Dian, (2015) Tradisi Bajapuik dan Uang Hilang Pada Perkawinan Adat Masyarakat Perantauan Padang Pariaman Di Kota Malang Tinjauan URF. Thesis UIN Maulana Malik Ibrahim Malang.

Sztompka Piotr. (2004). Sosiologi Perubahan Sosial. Semarang: PT Tiara W

Sugiyono. (2019). Metode Penelitian Pendidikan. Bandung: Alfabeta. 